\title{
Crisis conservation and green extraction: biodiversity offsets as spaces of double exception
}

\author{
Philippe Le Billon ${ }^{1}$ \\ University of British Columbia, Canada
}

\begin{abstract}
Extraction and conservation seem to be polar opposites, yet they entertain multiple relations as the 'greening' of extractive activities mobilizes conservation efforts to address the 'extinction crisis.' Drawing on a review of the literature and two case studies, this article discusses the politics of affinity and enmity shaping the extraction-conservation nexus, and partnerships. As crisis conservation and green extraction receive increased attention, the article suggests that the convergence of extraction and conservation is not only pragmatic, but also reflects shared discursive imaginaries and valuations of nature, practices materialized through spaces of 'double exception', and common politics of enmity directed at local communities that legitimize exclusionary practices rather than solve capitalism's contradictions.
\end{abstract}

Keywords: extraction, conservation, biodiversity offsets, land grabs, green grabs

\section{Résumé}

L'extraction et la conservation semblent être aux antipodes, mais elles entretiennent de multiples relations car le « verdissement » des activités extractives mobilise les efforts de conservation pour faire face à la « crise d'extinction ." S'appuyant sur une revue de la littérature et deux études de cas, cet article traite des politiques d'affinité et d'inimitié qui façonnent le lien extraction-conservation, et les partenariats. Alors que la conservation de crise et l'extraction verte reçoivent une attention croissante, l'article suggère que la convergence de l'extraction et de la conservation n'est pas seulement pragmatique, mais reflète également des imaginaires discursifs partagés et des évaluations de la nature, des pratiques matérialisées par des espaces de " double exception » et des politiques communes d'inimitié dirigée contre les communautés locales qui légitiment les pratiques d'exclusion plutôt que de résoudre les contradictions du capitalisme.

Mots-clés: extraction, preservation, compensations de biodiversité, accaparement des terres, rafles vertes

\section{Resumen}

La extracción y la conservación parecen ser polos opuestos, sin embargo, mantienen múltiples relaciones a medida que el "enverdecimiento" de las actividades extractivas moviliza los esfuerzos de conservación para abordar la "crisis de extinción." Sobre la base de una repasada de la literatura y dos estudios de caso, este artículo analiza las políticas de afinidad y enemistad que dan forma al nexo de extracción-conservación y las asociaciones. A medida que la conservación en crisis y la extracción verde reciben una mayor atención, el artículo sugiere que la convergencia de la extracción y la conservación no solo es pragmática, sino que también refleja imaginarios discursivos compartidos y valoraciones de la naturaleza, prácticas materializadas a través de espacios de 'doble excepción' y políticas comunes de enemistad dirigida a las comunidades locales que legitiman las prácticas excluyentes en lugar de resolver las contradicciones del capitalismo.

Palabras clave: extracción, conservación, compensaciones por biodiversidad, acaparamiento de tierras, agarra verde

\footnotetext{
${ }^{1}$ Professor Philippe Le Billon, Department of Geography and the Liu Institute for Global Issues, University of British Columbia, Canada. Email: philippe.lebillon "at" ubc.ca. I thank Bram Büscher and Ananda Siddhartha, guest editors of this special issue, and anonymous referees for their advice and comments. This work was funded by the Social Sciences and Humanities Research Council of Canada. This is the xx article in Bram Büscher (ed.). 2021. "Political ecologies of extinction", Special Section of the Journal of Political Ecology 28: 696-888.
} 


\section{Introduction}

Walking into Texaco's office in Angola in 1998 as part of an investigation on corruption in the oil sector, I was struck by a corporate poster promoting the company's oil rigs as a marvel of marine conservation. Arguably, oil rigs can serve as fish habitat and marine mammal observation platforms. But it's not their primary purpose. There were few justifications for Texaco to be in war-torn Angola other than profits. Conservation claims, I presumed, were there to inform visitors about the 'green' side of an industry mostly known for its catastrophic spills. Though not new, claims of biodiversity protection by extractive companies have increased over the past two decades and partnerships with conservation organizations are now frequent. While far from universal, conservation has become an intrinsic part of the ways many extractive companies portray themselves in the context of the contemporary 'extinction crisis.' After defending their corporate interests through denial and litigation, an increasing number of companies are repositioning themselves as unlikely 'defenders' of the environment (Adams 2017; Chapin 2004). Beyond environmental reclamation and carbon taxation, many are now pursuing green credentials through 'biodiversity offsets' and 'natural climate solutions' mobilizing conservation practices, including biodiversity and carbon sink protected areas, to reduce the environmental and emission impacts from their core operations (Maron et al. 2015). Denounced by some as "little more than an accounting trick to permit development" (Sweeney 2016: 13), these green extraction practices purport to achieve 'no-net-loss' or even 'net-positive-gain' biodiversity and emission impacts; ${ }^{2}$ with the financing of protected areas not only making up for, or exceeding the ecological devastation brought upon through extraction, but also creating new forms of capital accumulation (Adams 2017; Büscher and Fletcher 2015; Kelly 2011).

Extraction-conservation partnerships connect a wide array of organizations, objects, narratives, and practices, including extractive companies, conservation organizations, local communities, government authorities, geological formations, ecosystems, protected areas, carbon sinks, and endangered species lists. As discussed below, extraction and conservation partnerships have a broad set of costs and benefits (Adams 2017) and create unevenly distributed potential and realized values (Enns et al. 2019). Building on a growing political ecology literature investigating the articulation of extraction and conservation, I focus on the transformation of affinities and enmities across these two sectors. The strategic repositioning operated by select extractive companies and conservation organizations has first entailed a partial redefinition of allies and enemies, especially with regard to environmental organizations. It has also meant a reshaping of the exclusionary terrain of their (joint) operations, including through the combination of degazettement and biodiversity offsetting, enabling the production of spaces of exception where conservation and extraction regimes rule. This process, however, does not unfold without contention, contributing to a politics enmity often pitting local communities against as conservation and extraction interests frequently backed by the state.

Political ecology studies have extensively considered both resource extraction and biodiversity conservation, but more rarely their interactions (Huff and Orengo 2020). Here, I seek to contribute to the growing literature addressing this gap through a discussion of the political ecologies of extraction and conservation (Adams 2017; Büscher and Davidov 2016; Enns et al. 2019; Norris 2017; Purwins 2020; Symons 2018; ). Building on studies from within political ecology and other disciplines (see Sonter et al. 2018), I hope to help map out - both conceptually and literally - some of the main extraction-conservation relations.

From a conceptual perspective, I draw on political ecology - including inputs from 'new materialism', 'post-developmentalism', and epistemic 'decolonization' efforts (Schulz 2017) to discuss relations between extraction and conservation, with a focus on the ways extractive corporations and conservation organizations co-create spaces of double exception to secure their activities and realize value out of 'nature', whether out of commodity extraction, carbon credits, or ecotourism (Enns et al. 2019). For this, I briefly review some of the main current paradigms and trends in extraction and conservation, focusing on relations of affinity and enmity between the two and towards 'Others', focusing on local communities standing in the way of industrial extraction and neoliberal conservation. I then examine the effects of combined extraction and conservation

\footnotetext{
2 'Green extraction' refers here to discourses and practices seeking to represent extractive activities as environmentally benign, sustainable, or even beneficial (i.e. this is not to be confused with 'green minerals' extraction which includes deals with the extraction of metals and minerals for renewable energy technologies).
} 
logics, praxis, and consequences of these relations in specific places. Empirically, I seek to show how 'biodiversity offsets' and other 'natural climate solutions' represent dangerous tools of land reallocation, creating spaces of exception and annihilating 'traditional' socio-environmental forms of life. The main argument is that the politics of mutual affinity and common enmity between conservation and extraction mobilizes shared narratives and practices undermining opposition to neoliberal conservation and extractivism (i.e. logics of development through extractive activities), including false narratives of hope for the planet and conservationdriven spatial fixes to the damages of extraction, as well as new domains of capital accumulation from extinction and climate change mitigation.

Following this introduction, Section 1 provides a brief historical overview of relations between extraction and conservation. Section 2 outlines and conceptualizes the various spaces of exception articulated through these partnerships and their impacts on local communities, focusing on biodiversity offsets as conservation-driven 'natural solutions' to extraction and climate change. Section 3 briefly examines two case studies of biodiversity offsets, on coal mining in South Africa and agro-industrial plantations in Brazil, to illustrate some of the points made in this paper. The conclusion summarizes the main arguments, discusses major implications for conservation-extraction relations, and suggests areas for further research.

\section{Extraction and conservation}

Mostly identified as mining or oil and gas activities, extraction is more generally understood as the extirpation of select 'natural' materials for human purposes, including export-oriented commodity trade and industrial production such as logging, fishing, agriculture, and wildlife. Here, I follow a broader conception of extraction as transformative processes of dispossession and accumulation enabled by and exacerbating inequalities at the expense of pre-existing socio-environments (Douglas and Alie 2014; Van Vliet et al. 2016; Ye et al. 2020). I must note however that, first, most of the literature reviewed here more narrowly engages with the extraction of minerals and fossil fuels; second, many different forms of conservation and extraction exist (e.g. community-driven and multiple-use conservation areas intregrating small-scale extraction of forest products) with varying degree of conservation and extractivist pressures (Kröger 2020); and third, that local communities - and their individual members - are not 'automatically' opposed to conservation or extraction schemes (Andrews et al. 2017; Büscher and Fletcher 2020). Extraction and (neo)extractivism are increasingly used as concepts in the study of exploitation and subjectification within contemporary logics and practices of 'development' (Acosta 2013; Junka-Aikio and Cortes-Severino 2017; Veltmeyer 2016). Facing a negative public image and frequent resistance from local communities, some extractive companies have sought to advance claims of sustainability and contributions to climate change mitigation and biodiversity conservation (Boon 2019; Dahl and Fløttum 2019).

Many studies of extraction come from, or relate to political ecology approaches, especially as a result of the commodity boom initiated in the early 2000s (Bridge 2004), exposing uneven power relations in resource control and extractive governance (Peluso 1992), the ambivalent attitudes and effects of extraction (Bebbington 2008; Bridge 2008), the various forms of violence associated with extraction (Navas et al. 2018; Watts 2001), the numerous struggles against extractivism (Condé and Le Billon 2017; Temper et al. 2015), and increasingly common biodiversity conservation partnership between extractive and conservation actors (Enns et al. 2019). Following a brief background description of extraction and conservation, I then provide an overview of their interactions.

\section{Growth in extraction and conservation}

The past three decades have seen major reforms and debates around both extraction and conservation. Extraction 'boomed' during the period as mining outputs increased from 10 billion to 17 billion tons between 1990 and 2017 (Word Mining Data 2019), deforestation and agriculture further expanded in the tropics (Song et al. 2018), fishing efforts accelerated (Steneck and Pauly 2019), and a growing number of extractive projects affected high biodiversity areas and Indigenous peoples (Bebbington et al. 2018). Long present on the international agenda out of supply security concerns (Le Billon 2012), resource extractions received renewed attention as a result of diverse, and at times contradictory arguments and processes, such as the liberalization 
of mineral sectors, fears of 'peak oil', fast rising demand from 'emerging economies', developmental concerns over a 'resource curse', critiques of 'land grabbing', widespread struggles against extractive projects, and broader concerns over climate change (Bridge and Le Billon 2017; Temper et al. 2020). While faint hopes of a transition to a 'low carbon economy' may reduce fossil fuel exploitation by mid-century (Le Billon and Kristoffersen 2020), mining of 'green transition' minerals is intensifying (Sovacool et al. 2020).

Conservation activities also increased over the past three decades. Worldwide terrestrial and marine protected areas grew from $8.2 \%$ to $15 \%$ and $0.4 \%$ to $7.6 \%$ between 1990 and 2019, respectively (PPLR 2020). The conservation agenda experienced major upheavals, including over broader concerns for biodiversity loss (e.g. the 1992 Convention on Biological Diversity), as well as forceful conservation practices and transnational conservation instruments using market mechanisms (e.g. REDD+). Political ecology critiques have exposed the neoliberalization of conservation and its growing militarization, denouncing the exacerbation of uneven power relations and the creation and capture of new values at the expense of others, mostly those of traditional communities, especially Indigenous groups (Büscher et al. 2017 ; Colchester 2004; Duffy 2014; Peluso 1993). Conservationists have stressed efforts to advance multiple-use conservation areas, attention to human rights dimensions, and support for in-situ and community-driven conservation projects (Jonas et al. 2017; Newing and Perram 2019; Shaw 2021). Examples of community-based conservation and extraction, include Brazil's 'extractive reserves' (RESEXs), originally designed to protect sustainable extractive processes by small-holders but increasingly threatening forested landscapes through more severe forms of communitarian logging schemes (see Kröger 2018; 2020).

Despite the apparent contradictions or dichotomies between extraction and conservation, both share many similarities including common dialectical imaginaries and materialities, reshaping landscapes for their own purposes (see Table 1; Bridge 2001; Davidov and Büscher 2013). As Norris (2017) points out, both sectors seek to commodify nature and calculate the value of these commodities (proven mineral resources and protected areas marketed for tourism) in order to persuade landowners to accept these new land use regimes or surrender their lands through a mix of (false) promises, ontologically incompatible compensation schemes, and outright coercion (Adams 2017; Brock 2020; Watts 2000). Both extraction and conservation work, at times together, in order to bring about new imaginaries of places and re-territorialize them through regimes of exception that seek to rule and legitimize particular forms of exclusion or inclusion, in particular for local communities.

As discussed here, extraction and conservation share in this regard some common enmities, notably towards local communities, migrants, land uses and livelihoods that are seen as incompatible with large-scale extraction and mainstream forms of conservation. As a result, growing affinities between extraction and conservation have resulted in a flurry of initiatives on both sides (see Table 2). For critics, these affinities are in effect not only 'sustaining extraction' through green washing, engagement in conservation, or post-extraction rewilding, but also 'sustaining extinction' through the continued promotion of extraction.

\section{Extractive footprints and tensions with conservation}

Extraction and conservation entertain multiple and complex relations. Many extractive activities are taking place in conservation-valued areas, such as with mining and oil extraction in the Western Amazon (Butt et al. 2013; Finer et al. 2008; Sonter et al. 2017). About $86 \%$ of industrial mines for key metals around the world are located in areas of high or intermediate plant diversity (Murguia et al. 2016), and about a third are either inside or within $10 \mathrm{~km}$ of a protected area (see Durán et al. 2013). This threatening proximity, or blatant overlap, is pushing some major conservation organizations to work with extractive companies and their financiers, often based on the argument that "minerals will still need to be mined, even in a fully renewable age. Any extractive activity must [therefore] be conducted in an environmentally and socially responsible way, causing the least possible damage" (WWF 2019). The damages of extraction have indeed been extensively documented (Butt et al. 2013; Fisher and Burton 2018; Meijaard et al. 2005; Radford 2012). The numerous socio-environmental impacts of extraction have generally pitted local communities and allied environmental organizations against extractive projects (see Temper et al. 2015). In turn, many extractive companies have coercively pushed against resistance to their projects, generally with the active support of host country 
authorities and local elites (Condé and Le Billon 2017). Discourses of enmity and coercive types of practices have been deployed by parties on all sides, with civil society groups denouncing companies, boom-town speculators (including pro-extraction local elites) as reckless, heartless and greedy (Dahlgren 2019; Wouters 2020); companies criticizing environmental and land defenders as subversive anti-development radicals (Middeldorp and Le Billon 2019) and local pro-extraction groups attacking environmental activists (Welker 2009); and governments portraying local - often Indigenous - communities as backward people in need of modernity (Dunlap and Jakobsen 2020; Prause and Le Billon 2021; Purwins 2020). The result has often been escalation of conflicts over extractive activities, leading in turn to grave human rights abuses including murders (Le Billon and Lujala 2020). Yet, not all 'stakeholders' in extraction/conservation debates have pursued a confrontational approach in extraction/conservation relations. As documented below, many major western extractive companies and conservation NGOs have come to closely collaborate for the purpose of advancing extraction and conservation.

\begin{tabular}{|c|c|c|}
\hline Category & Extractive companies & Conservation organizations \\
\hline Operational goal & Extraction & Protection \\
\hline Economic perception & Promised development & Wasted potentials \\
\hline Environmental image & Destructive & Protective \\
\hline Financial motivations & Profits & Charitable funding \\
\hline Material interest & $\begin{array}{l}\text { Subsoil resources and agro-productive } \\
\text { soil and water }\end{array}$ & Surface biodiversity and ecotourism \\
\hline Areas of interest & $\begin{array}{l}\begin{array}{l}\text { Resource frontiers and commercial } \\
\text { deposits }\end{array} \\
\end{array}$ & High biodiversity and critical ecosystems \\
\hline $\begin{array}{l}\text { Spatial logics and forms of } \\
\text { control }\end{array}$ & $\begin{array}{l}\text { Erasure of previous land use and } \\
\text { exclusion or integration of local residents; } \\
\text { Concession and surface/sub-surface terra- } \\
\text { transformation }\end{array}$ & $\begin{array}{l}\text { Re-naturalization of land ('without use') } \\
\text { and exclusion or co-management with } \\
\text { local residents; Protected areas and Other } \\
\text { Effective Area-based Conservation } \\
\text { Measures (OECMs) }\end{array}$ \\
\hline Security & $\begin{array}{l}\text { Militarization and community } \\
\text { pacification through Impact Benefit } \\
\text { Agreements, Corporate }\end{array}$ & $\begin{array}{l}\text { Militarization and community enrollment } \\
\text { through eco-tourism, 'sustainable' } \\
\text { livelihoods, REDD+, and repression }\end{array}$ \\
\hline
\end{tabular}

Table 1: Comparison of extraction and conservation.

\section{Growing affinities between extraction and conservation}

As the 'professional' embodiment of biodiversity protection, conservation organizations (COs) have increasingly partnered with extractive industries. As an often already corporate-friendly branch of the broader family of environmental non-governmental organizations (ENGOs), COs are frequently funded by highearning individuals and their foundations (Holmes 2012; Spence 1999; Tsing 2005), build their programs on the legacies of (extractive) colonial conservation practices, and do not hesitate to use a 'firm' (and deadly) hand with local populations protecting their traditional livelihoods or resisting relocation as a result of 'fortress conservation' (Duffy 2014). Some conservation projects have extended or even directly benefited from the dispossession of traditional residents, including Indigenous people, as in the case of gold mining in Yosemite National Park (Spence 1999). Conservation can be instrumented as a 'green alibi' to displace communities and more easily access mineral resources, as reported in the case of diamonds for the Basarwa in Botswana (Boonzaier 2011; Mosweunyane 2017). Many COs have long welcomed funds from extractive companies (Chapin 2004). Direct funding from extractive corporations rose from the mid-1990s onward, often with 
different purposes in mind. Rather than green philanthropy perhaps assuaging the guilt of old deeds and dreams of 're-wilding' places, the more recent corporate funding is 'future oriented' and often seeks to secure future environmental licence for extractive activities as well as producing future (and new) values out of 'nature.'

Taking the form of public relations campaigns, hired consultancy, operational sub-contracting, and strategic partnerships, these 'new' relations have thus been more instrumental in enrolling conservation within on-going and future extractive activities. In this regard, COs have been able to facilitate the conservation claims and projects of extractive companies through their 'green' brand, conservation expertise, and extensive networks. At its most basic, these relations have allowed extractive companies to populate their sustainability reports with images of charismatic wildlife, ecofriendly 'natives', and the green logos of conservation. At its most elaborate, extraction-conservation partnerships have created and run vast protected areas, or led to the codesign of corporate strategic plans on future climate policies. By the mid-1990s, the interest of major conservation NGOs in further engaging extractive companies found an echo in the interest of a number of large Western mining companies to improve their environmental practices and image (Adams 2017; see Table 2).

\begin{tabular}{|l|l|}
\hline Year & Initiative name and main proponents \\
\hline 1997 & Reinventing the Well - Conservation International \\
\hline 1998 & Global Mining Initiative (GMI) \\
\hline 1999 & $\begin{array}{l}\text { Mining, Minerals and Sustainable Development (MMSD) project and creation of the International } \\
\text { Council on Mining and Minerals (ICMM) }\end{array}$ \\
\hline 2000 & Lightening the Lode - Conservation International \\
\hline 2001 & $\begin{array}{l}\text { Energy and Biodiversity Initiative (EBI) - BP, ChevronTexaco, Shell and Statoil / Conservation } \\
\text { International, Fauna \& Flora International, the Nature Conservancy and the Smithsonian Institution }\end{array}$ \\
\hline 2004 & Business and Biodiversity Offset Program (BBOP) - CI, Forest Trends/Newmont \\
\hline 2006 & Good Practice Guidance for Mining and Biodiversity - ICMM \\
\hline 2011 & $\begin{array}{l}\text { Toward Sustainable Mining and Biodiversity Conservation Framework reporting - Mining } \\
\text { Association of Canada }\end{array}$ \\
\hline 2013 & $\begin{array}{l}\text { Independent Report on Biodiversity Offsets. The Biodiversity Consultancy, International Council } \\
\text { on Mining and Metals (ICMM), International Union for Conservation of Nature (IUCN). }\end{array}$ \\
\hline 2019 & Forest-Smart Mining - World Bank / Fauna and Flora International \\
\hline
\end{tabular}

Table 2: Timeline of major reports and initiatives articulating extraction and conservation Sources: Adams (2017); author.

Beyond individual relations between extractive companies and COs, major national mining associations also called for greater engagements with stakeholders, and in particular partnerships with conservation organizations (Bowles and Prickett 2001; ICMM 2006). A 'Triple A' rating on biodiversity within the Mining Association of Canada, for example, required "a commitment to actively partner with other organizations for biodiversity conservation" (MAC 2017, emphasis added). Asked how she would respond to critiques of a US\$50 million partnership with Australian mining giant $\mathrm{BHP},{ }^{3} \mathrm{CI}$ 's senior director for responsible mining and energy responded that "[T]he world needs the expertise, agility and funding the private sector brings to the table to tackle and scale conservation solutions" (Evans 2019). In 2011, a sting operation by journalists exposed the apparent willingness of CI corporate relations staff to help 'greenwash' a (mis-represented) US arms company through conservation areas in the Middle East that would be associated with the company's

\footnotetext{
${ }^{3}$ BHP is a Top 20 Global Carbon Major (Taylor and Watts 2019) with 177 million tons of embedded $\mathrm{CO}_{2} \mathrm{e} / \mathrm{year}$ from its
} Australian coal mines (Moss 2019). 
"Endangered Species Mascot" (Lewit 2011); companies could sit on CI's Business and Sustainability Council for a US $\$ 100,000$ fee (DPL 2012). ${ }^{4}$ Extractive funding of conservation has been allocated to various purposes, including biodiversity research, training wardens, and extending parks (see below, Table 3). Such funding can also be part of counterbalancing specific negative media coverage of an extractive company, as suggested by Hamann and Kapelus (2004) in the case of First Quantum in Zambia, which announced conservation funding shortly after facing criticisms for low tax payments. In short, the past two decades have seen a growing affinity between extractive companies needing green credentials and expertise, and conservation organizations needing access and finance.

Despite these growing affinities and accompanying critiques, not all researchers working on links between extraction and conservation agree. Based on their extensive review of studies on mining and biodiversity, Sonter et al. (2018: 2) argue that there is fact a lack of long-term collaboration between mining and conservation interests, and scientific uncertainties have so far "resulted in a simplification of complex and often controversial issues" (emphasis added). False or questionable arguments by extractive companies and partnering organizations include prognoses that improving extractive technologies and resource recycling will drastically reduce future biodiversity loss, that extractive activities will have insignificant consequences compared to other processes such as agriculture, and claims by extractive companies that they are now fully committed to environmental protection when efforts still in part depend on market conditions. Sonter et al. (2018) thus suggest that greater and higher quality engagement between extraction and conservation may help prevent biodiversity loss from extraction, including through financing conservation efforts and alternative paths for environmentally damaging local livelihoods that could improve 'sustainable development' performances (see also WWF 2019). Yet, some concerns remain about both the motives and effects of closer affinity between extraction and conservation.

\section{Explaining extraction and conservation partnerships}

Mobilizing insights from critiques of 'neoliberal nature', Enns et al. (2019: 969) have argued that not only "extraction and conservation activities increasingly occur in the same spaces and make use of similar logics, strategies and technologies", but that "biodiversity conservation is increasingly being carried out through partnerships between extractive and conservation actors in pursuit of shared or complementary interests" (see also Büscher and Davidov 2013; Norris 2017; Seagle 2012). Several factors or motives explain these partnerships.

The first explanation is the neoliberalization of much of conservation, which "shift[ed] the focus from how nature is used in and through the expansion of capitalism, to how nature is conserved in and through the expansion of capitalism" (Büscher et al. 2012:4). Lured by market-based neoliberal forms of conservation and the promises of a green economy, Adams (2017: 245) argues, many conservationists have been willing to "sleep with the enemy ... turning a blind eye to their own past and to the working of neoliberal capitalism, showing a remarkable willingness to entertain future risks to biodiversity from the outworking of neoliberalism." Seeing in this relationship a Faustian Bargain, Adams (2017) sums it up by suggesting that conservation organizations passed a deal with corporations to "acquire power in exchange for the soul... giving up their innocent objection to the destructiveness of capitalism." Rather than 'failing' state-funded conservation, neoliberal conservation, and capitalist expansion more generally, is seen by these organizations as offering the promise of effective biodiversity conservation through a green economy (Igoe et al. 2010).

Secondly, this neoliberalization provided the extractive sector facing a double crisis of legitimacy and exhaustibility with a spatial fix, opening up new lands and reserves, and an ecological fix, flipping conservationists from opponents to partners through market solutions (Enns et al. 2019; O'Connor 1988). In short, conservation organizations could save nature by helping corporations bring it to markets (Adams 2017; Büscher et al. 2012). For Dempsey and Suarez (2016: 267), neoliberalization logics mean that conservationists "must now court, rather than confront" extractive companies. Such courting, in turn, could lead both sectors to

\footnotetext{
${ }^{4}$ According to its own annual financial reports, CI had raised US\$36.1 million directly from corporations in 2013 (CI 2014). By 2018, CI counted support from 5 fossil fuel companies, 7 mining companies, and 3 agro-industrial (palm oil) companies; with Chevron, Exxon, and Shell as Business and Sustainability Council members (CI 2019).
} 
profit from the official (re/de)valuation of nature (Dempsey and Collard 2017). In short, conservation organization and extractive companies mutually help each other to produce new "capitalist natures" (Kay and Kenney-Lazar 2017: 306), and through this "secure the foundation upon which their production and accumulation is based" (Enns et al. 2019: 970).

Pragmatically, this means, for example, that conservation organizations partner with extractive companies because their model requires more funds and access to higher-level power-holders. Among environmental organizations, conservation organizations are more likely to partner with extractive companies as they seek the support of government authorities, rather than challenge them. Conservation organizations with large budgets are also more likely to partner with extractive companies (Hoffman 2009), ${ }^{5}$ something that not only reflecs their greater capacity but also their need to secure large and diversified revenue streams. Funding from extractive companies can also help COs pursue approaches that would alienate more 'traditional' conservation donors, with for example companies being more willing to support agricultural and livelihood schemes for local communities to increase their cooperation in conservation activities, while traditional conservation donors may refuse to fund programs supporting local community residence and activities (see Hance 2016).

Extractive companies partner with conservation organizations in part because they need to improve or protect their reputation through green credentials; to prevent or remediate environmental harms; to secure their activities through a controlled perimeter/buffer zone; and to create new ways of valuing their investments. For this, they need to access conservation 'expertise' (e.g. biodiversity conservation and carbon offsetting), recognized policy advice, field capacity and networks, as well as trust-building intermediaries to reach out to local authorities and select communities. Furthermore, partnerships also result from similar approaches that develop assets frequently against the will and traditional livelihoods of local residents, and they can also benefit from mutual communication (Read and Diehl 2018). Their logistics can be facilitated when they work in the same geographical areas.

Finally, conservation can render land around extractive sites 'investable' (Le Billon and Sommerville 2017), notably through eco-tourism (Büscher and Davidov 2016). Without conservation, local residents may be seen by extractive interests as a threatening 'surplus population' in need of costly pacification. Through their partnership, conservation and extraction can render the land 'investable' not only for extraction - by reassuring investors through increasing the green credentials of the project and lowering reputational risk - but also for conservation, as environmental organizations benefit from a source of funding and benefit from some of the extractive infrastructure, such as roads and local air strips, to develop ecotourism (Smith 2013). This new source of value, in turn, can be used to the advantage of extractive companies to buy in local communities through new livelihoods and 'co-management' as well as keep migrants at bay through stricter human settlement rules, including at times with the support of local elites asserting exclusive ethnic/tribal entitlements (Wouters 2020).

\section{Enmity and the Extraction-Conservation nexus}

In Necropolis, Achille Mbembe $(2019,16)$ explains how the "state of exception and relation of enmity have become the normative basis of the right to kill... [as] power ... continuously refers and appeals to the exception, the emergency, and a fictionalized notion of enmity." Enmity, he continues, "now constitutes the spirit of liberal democracies, and how hatred gives them the impression of experiencing a pure present, a pure politics, using means that are themselves pure." In the case of the extraction-conservation nexus, such politics of enmity are mostly directed at individuals and groups resisting extraction and conservation projects. More recently identified in the literature through the term 'environmental and land defenders' (Menton and Le Billon 2021), these individuals and groups are often Indigenous and traditional agrarian communities facing a criminalization of their land uses (e.g. shifting agriculture), livelihoods (e.g. artisanal mining, hunting), and practices of resistance (e.g. refusal to relocate, protests, blockades) - echoing coercive processes anchored in

\footnotetext{
${ }^{5}$ One could also hypothesize that conservation organizations with a low ratio of membership to budget are more likely to partner with extractive companies, although this remains untested.
} 
colonial and racist 'rationalities' (Mbembe 2001) that have been well documented within the political ecology literature (e.g. Neuman 2004; Walker 1998).

As Hill et al. (2016: 310) summarize, political ecologists "recognize that relationships among bigbusiness operations and local resource management institutions are complex and interactive in the context of historically and politically contingent circumstances of protected area designation and management." Seemingly benign forms of inclusion into extraction and conservations schemes - such as ecotourism funded through extractive companies as part of their corporate social responsibility programs - can, for example, result in deeper intra-community inequalities and conflicts (Palmer and Chuamuangphan 2018), pointing to the importance of post-development approaches (Duffy 2006; Büscher and Fletcher 2020). At least seven major conservation activities associated with extractive companies can be identified, from the commissioning of conservation research to the creation of new protected areas. While some of these activities can have positive impacts for some communities, or at least for some of their members (e.g. easier access to health services and additional sources of livelihoods reducing out-migration, see Smith 2013), they also - if not mostly - have potential negative impacts (Enns et al. 2019; Table 3).

\begin{tabular}{|l|l|}
\hline $\begin{array}{l}\text { Conservation activities of extractive } \\
\text { companies }\end{array}$ & Potential negative impacts on local communities \\
\hline Commissioning conservation research & $\begin{array}{l}\text { Shift in understandings of value for 'nature' and potential } \\
\text { land use for area; extractive bioprospecting }\end{array}$ \\
\hline $\begin{array}{l}\text { Raising community awareness about } \\
\text { conservation initiatives }\end{array}$ & $\begin{array}{l}\text { Shaming of traditional practices and closure of alternative } \\
\text { 'sustainabilities' to those allowed by conservaiton }\end{array}$ \\
\hline $\begin{array}{l}\text { Initiating captive breeding and rewilding } \\
\text { programmes }\end{array}$ & Increased risk of damage from wildlife \\
\hline $\begin{array}{l}\text { Establishing community-based } \\
\text { conservancies and resource management } \\
\text { programs }\end{array}$ & $\begin{array}{l}\text { Increase in inequalities, including uneven distribution of } \\
\text { revenues increasing intra-community inequalities and } \\
\text { tensions }\end{array}$ \\
\hline Training and equipping park rangers & Increase in fines and human rights abuses \\
\hline $\begin{array}{l}\text { Building new security infrastructure in and } \\
\text { around protected areas }\end{array}$ & Further loss of access to land and resources \\
\hline Establishing new protected areas & $\begin{array}{l}\text { Restriction of a land and resource access; displacement; loss } \\
\text { of assets; increase in tourism }\end{array}$ \\
\hline
\end{tabular}

Table 3: Impacts of extraction-conservation partnerships on local communities. Sources: Enns et al. 2019; author.

To sum up, by fixing some of the crises of extraction, conservation enables its reproduction, or in other words helps to 'sustain extraction.' While conservation initiatives may help to counterbalance some of the 'bads' resulting from extraction, the resulting extraction-conservation system also extends its own impacts onto communities and the world at large - including the planet's ecosystems. The predictable endgame of these phyrric victories is unlikely to be the win-win that many conservationists are claiming to pursue, but rather the incorporation of conservation into extractivist logics. To use Dunlap and Jakonsen (2020)'s take on violent technologies of extraction, the conservation organizations that are participating in this Faustian bargain may be at risk - intendedly or not - of paradoxically constituting one of the "insatiable forces that transform, convert and consume the world." 


\section{Extraction, conservation and spaces of exception}

If affinities between extraction and conservation can take shapes, they are increasingly translating on the ground into the formation of various types of spaces of exception. As presented in Figure 1, initial exceptions creating conservation or extraction areas, are reworked through relational assemblages bringing in their supposed 'polar opposite.' Although this matrix oversimplifies more complex relations, with four main categories being identified when considering the initial spaces of exception - whether conservation or extraction - and the pursuit of purposes through practices. Each of these create particular spaces of 'double' exception related to conservation and extractive regimes of rule; noting that this 'double' aspect generally does not come out of direct, simulataneous and overlapping co-occurrence of conservation and extraction in time and space, but rather through various processes of chronological succession or indirect spatial relations between these regimes of rule.

First, existing conservation areas can be de-gazetted for the specific purpose of extraction, creating nested spaces of exception within (former) conservation areas that had already imposed rules of exception evicting local populations or severely restricting livelihoods and land uses (see Figure 1a); in this case one regime of exception (extraction) chronologically succeeds the other (conservation), possibly to serve as a spatial fix of extraction elsewhere (e.g. the exhaustion of a company's ore deposits in other mined areas). Second, the outer perimeter of an existing extraction area can be turned into a conservation area for the specific purpose of securing extractive activities in the core area through a peripheral regime of exception (see Figure 1b); in this case a new regime of exception (conservation) is spatially juxtaposed with the area under the extraction regime in order to protect and partially extend it (e.g. serving as a 'natural' - and possibly lower-cost - equivalent of 'social' perimeters through which extractive companies seek to pacify nearby communities to protect their core activities). ${ }^{6}$ Third, current or former extraction areas can be turned into conservation areas, such as one combining, for example, a 'reclaimed' high biodiversity conservation area overlay atop a previous zone of extraction, thereby maintaining a regime of exception and avoiding possible future liabilities through preventing a re-settlement of the area (see Figure 1c); in this case the conservation regime temporally follows the extractive one over the same spatial 'footprint', preventing the return of populations and their liability claims (e.g. 'rewilding', environmental reclamation covering up for environmental liabilities and participating in economies of accumulation through restoration, see Brock 2020). Finally, new conservation areas can also be created specifically for the purpose of offsetting extraction, there creating a space of double exception at $a$ distance from the existing area of extraction (see Figure 1d); in this case an off-site conservation regime is imposed or reinforced in order to 'compensate' for the impacts of an extractive one, with the result of doubling the total area coming under either of these two regimes of rule - noting that each legitimates and justifies the other.

\section{Degazetted PAs}

The most common form of double spaces of exception is the exception made by authorities for extractive projects to take place within conservation areas, themselves spaces of exception given their restrictive land access and land use rules. The proportion of designated protected areas increased from about $8 \%$ to $15 \%$ of terrestrial areas and from 1\% to 10\% of marine areas between 1990 and 2016 (UNEP-WCMC and IUCN 2016). The rate of protection has been decreasing however, with protected areas downgrading, downsizing, or degazettement (PADDD) becoming increasingly frequent, in large part to allow for resource extraction activities (Kroner et al. 2019; see also Mascia and Pailler 2011). Of 3,718 PADD events identified between 1892 and 2018, 78\% were enacted between 2000 and 2018, while several countries, such as Bolivia, also authorizing extractive activities within some protected areas from the onset of their establishment (Kroner et al. 2019).

\footnotetext{
${ }^{6}$ On the concept of 'pacification' of communities including corporate counter-insurgency approaches mixing repressive and cooptation mechanisms, see Dunlap and Jakobsen (2020) and Huff and Orengo (2020).
} 


\begin{tabular}{|c|c|c|}
\hline $\begin{array}{l}\text { Spaces of } \\
\text { double exception } \\
\text { Initial } \\
\text { spaces of exception }\end{array}$ & $\begin{array}{l}\text { Extraction overlaid on or } \\
\text { underlaid below conservation }\end{array}$ & $\begin{array}{l}\text { Conservation appended to } \\
\text { extraction }\end{array}$ \\
\hline Conservation areas & $\begin{array}{l}\text { Degazetted PAs } \\
\text { Spaces of extraction within protected } \\
\text { areas }\end{array}$ & $\begin{array}{l}\text { Conservation perimeters } \\
\text { Spaces of conservation around } \\
\text { extraction areas }\end{array}$ \\
\hline & $1 \mathrm{a}$ & $1 b$ \\
\hline Extraction areas & $\begin{array}{l}\text { Extractive cover-up PAs } \\
\text { Spaces of conservation overlaid on } \\
\text { (former) extractive areas }\end{array}$ & $\begin{array}{l}\text { Extraction offsets } \\
\text { Spaces of conservation 'offsetting' } \\
\text { extractive areas }\end{array}$ \\
\hline & $1 \mathrm{c}$ & $1 \mathrm{~d}$ \\
\hline
\end{tabular}

Figure 1 - Extraction, conservation and types of spaces of double exception.

Overall, while the trend of future gazettement of terrestrial protected areas is unclear, it seems likely that greater accommodation of extractive activities will take place in high biodiversity areas, both for lands and oceans, whether formally (and practically) protected or not (Ali et al. 2018). On land, continued growth in fossil fuel extraction, increased mining targeted at green energy transition, as well as extensive agro-industrial projects point to sustained pressure on high biodiversity areas (Díaz et al. 2019). For oceans, there is a major concern that 'blue growth' - the pursuit of economic growth through marine spaces and resources, will result in major socio-environmental impacts (see Bennett et al. 2019). The influence of resource reserves has not been tested, but is likely a factor and deserves further research. Enacted PADDD events in the Amazonian region between 1961 and 2017 were overwhelming associated with industrial-scale resource extraction and development (83\%) compared to local land pressures and claims (9\%). Of these events 67\% were later reversed and 5\% were offset (Kroner et al. 2019). As Naughton-Treves and Holland (2019, 833) remark "some park downgrades, such as those granting access rights to long-term residents, may be pragmatic steps to help build local constituencies for conservation or encourage more sustainable harvest levels... Far greater concern should 
be given to the permanent changes brought by extractive industries and infrastructure in and around protected areas."

\section{Conservation perimeters and extractive-areas-turned-PAs}

Extraction has not only led to PA degazzettements, but also to the funding and creation of PAs. This has taken several forms, including the funding of new or already existing protected areas, the conservation of industrial landscapes tied with environmental objectives, as well as the environmental remediation and turning of extractive zones into PAs. These areas often constitute new spaces of exception, as the exclusions brought by extractive companies are replaced or complemented by those of conservation. In Germany, the 'lake' created by the Haselbach 1 coal mining has been turned into a protected area, its toxic waters being covered with coconut fiber mats seeded with reeds to create an artificial 'pleasant wetland' that is strictly off limits to local populations, in part because of drowning risks (Mudroch et al. 2002). Some companies have also established 'conservation perimeters' around core mining areas to protect and legitimize their extractive activities (Zambian Eye 2018), as well as advertised conservation areas within their concessions (i.e. 'set-asides') to attract and recruit expatriate workers (e.g. 'careers' section of First Quantum website for its Kansanshi and Sentinel copper mines $\left.{ }^{7}\right)$.

\section{Extraction offsets (aka 'biodiversity' offsets)}

Conservation area offsets allow for extraction in conservation-valued sites in exchange for the application of conservation regimes in other (supposedly near-equivalent) biodiverse areas (Bull and Strange 2018). Rather than calling for less extraction, some conservation organizations instead called for extractive companies to fund large 'biodiversity offsets' (Virah-Sawmy et al. 2014); noting here that the correct term should instread be 'extraction offset' since it is extraction (and its narrow ontological perspective and valuation of nature and life) that these schemes are trying to compensate for, and not the biodiversity that is being ravaged (on the ontological dimensions of extraction and compensation, see Lassila 2020; Le Meur et al. 2020; Li 2015). This risks not only legitimating and even further promoting extraction, including in high biodiversity areas since offsets supposedly offer a compensatory mechanism, but some critiques have warned that governments misuse offsets to reach their CBD protected areas commitments, thereby promoting extraction while pretending to advance conservation (Maron et al. 2015).

Biodiversity offsets are generally operationalized through the creation or extension of private protected areas, often with ownership held by conservation organizations (Büscher 2021; Thakholi 2021). In Canada, Shell purchased about 18,200 hectares through several conservation organizations, including the Alberta Conservation Association, Ducks Unlimited Canada, and The Nature Conservancy Canada (Shell Canada 2019). Teck similarly funded TNCC to the tune of US\$2 million for conservation offsets (TNCC 2013). Seeking to offset unconventional oil and gas or large-scale mining projects, some of these initiatives turned settler ranches on unceded Indigenous lands into 'private conservation properties', raising issues about entrenching Indigenous dispossession (Hackett 2015). Some of these conservation organizations, however, have also bought out extractive companies to prevent possible gold and coal development, combining compensation of extractive licence cancellation with new 'no-go' area regulation by legislators (Chaney 2011). Partnerships with Indigenous groups over offsets also occur, but while some form of community engagement generally takes place, the respect of a right to free, prior and informed consent (FPIC) is often complex and constrained (see Macintyre 2007). FPIC for example can be restricted to officially-recognized Indigenous groups rather than traditional or local communities, consent itself not secured before projects are implemented, and prior consulation may be used as means to carry out extraction rather than veto it (Jenner and Balmforth 2015; Hackett 2015; Middeldorp and Le Billon 2021).

Offsets remain relatively rare in relation to existing Protected Areas. Out of 268 enacted PADDD with planned offsets, only 13 were actually carried out (Kroner et al. 2019). This suggests that offsets could be misused as a planning approval diversion, with companies only pretending that they will provide offsets. There

\footnotetext{
${ }^{7}$ See https://www.first-quantum.com/English/careers/work-and-lifestyle/zambia/default.aspx.
} 
are also documented cases of offsets that have been themselves 'offsetted', leading to a string of extractionconservation-extraction-conservation across landscapes. Biodiversity offsets are becoming more common for projects taking place outside of PAs, with a recent study identifying 12,983 offset projects extending over around 150,000 $\mathrm{km}^{2}$ across 37 countries (Bull and Strange 2018), and more research is needed in regard to actual implementation levels and the long-term status of offsets. So far, relatively few studies have examined the social impacts of biodiversity offsets (see World Bank 2019). Among these, research on the Ambatovy nickel mine offset projects in Magagascar have found that the more immediate costs of conservation restrictions on affected populations have not been addressed through alternative livelihood benefits or compensation. Examples are the loss of access to nearby forests (Neimark and Wilson 2015), and the uneven distribution of costs and benefits within communities (Bidaud et al. 2017).

Offsets are presented as a way to compensate for biodiversity losses in areas undergoing extraction. They frequently take place at the expense of two categories of local populations: those whose lands are being directly affected by extractive activities, and those whose lands are turned into offsets (or 'offsetteered'). In turn, these populations have been framed as representing a challenge for the extraction-conservation nexus. A review of five mining-related biodiversity offsetting schemes commissioned by the World Bank (2019) clearly identified the 'common enemies' of the extraction-conservation nexus. Among the eight "practical challenges encountered in offset implementation" identified by the report, seven related to the presence and practices of local communities, including charcoal production, fuelwood collection, small-scale logging, hunting for bushmeat, fire-based land management, agricultural encroachment, and more generally 'access' to protected forests. The only non-community related challenges was the slow biodiversity recovery observed in restored landscapes where topsoil had been removed or highly impacted. The report left little to the imagination, other than local people being the main impediment to successful offsetting by large-scale mining. In Ghana, Newmont 'offsetted' its Akyem mine in Ajenjua Bepo Forest Reserve through funding for increased enforcement by park rangers in Mamang Forest Reserve via BBOP to reduce land 'squatting', 'illegal' logging, and 'poaching' by the local population (MacDonald 2008). In Madagascar, a managing officer charged with implementing a new offset regime described some affected people as lazy "parasites" with "primitive minds" unwilling to work on the alternative livelihood schemes proposed by his organization (Vyawahare 2020). Biodividersity offsets have frequently displaced farming livelihood options and thereby populations, acting in effect as a tool of dispossession (Hackett 2015, 2016).

One of the major issues with biodiversity offsets is the problematic ways of assessing the 'biodiversity loss' associated with projects. Such assessments often fail to adequately consult local communities and the values that they put on this biodiversity, and on land more generally. In Laos, critics have pointed to dam biodiversity offset schemes as one more way the government tries to end shifting agriculture practices, with drastic consequences for traditional livelihoods and food security (WRM 2017). Because offsets facilitate the issuance of extraction permits, while at the same time expanding lands under restrictive conservation rules, there is a risk of seeing a general acceleration and amplification of the process. Some conservationists have called for biodiversity offsets to follow a precautionary approach and for example to double the size of the biodiversity offset area compared to the extraction area (Virah-Sawmy 2014). This would mean that for every hectare granted to an extraction project, communities could in effect lose three. In South Africa, AngloAmerican/De Beers has committed to create 45 hectares of conservation area (mostly in the form of game reserves) for every hectare of land used for mining, its website proudly claiming to have 'strengthened' already 'robust' anti-poaching measures to protect wildlife (De Beers 2018).

Looking at the case of Rio Tinto/QMM's ilmenite ${ }^{8}$ mine in Madagascar, Seagle (2012: 447) concludes that the commodification, economic valuation and objectification of nature coming out of the extractionconservation nexus enabled a process of inversion whereby the extractive project's threat to biodiversity paradoxically enabled the company's claim "to be 'saving' biodiversity from local Malagasy people." Examining the same case nearly a decade later, Huff and Orengo (2020) conclude that "[the offset] has triggered serious social, environmental and legal conflicts since its inception, including allegations of a 'double land grab' to accommodate mining activities and compensatory biodiversity offsetting", and they add that the 'pacification'

${ }^{8}$ Titanium is refined from ilmenite. 
of local communities works "...through the re-ordering of socio-nature, underwrites the forms of 'security', 'stability' and even 'sustainability' that facilitate multiple and overlapping strategies of value extraction in the territorial and extra-territorial spaces occupied by the QMM mine partnership."

This is made in part possible through a process of offsets reframing nature as isolated and exchangeable biodiversity units, obfuscating the social dimensions of biodiversity and deep local entanglements between the human and non-human, commodifying and financially valuating biodiversity, and recasting biodiversity as a positive by-product of economic growth and land development rather than as a negative impact (see Apostolopoulou and Adams 2017; Thakholi 2021). Biodiversity offsets are also often seen by large-scale extractive companies as providing an edge against competing firms, as well as a way to further delegitimize, if not criminalize, certain livelihoods. As early as 2008, industry specialists anticipated that biodiversity offsets would help large-scale operations be "seen as the preferred development option compared to unregulated and poorly run operations... includ[ing] artisanal and small-scale mining" (Nazari and Proebstel 2008: 43). Below, I briefly look at two examples of offsets, and the politics of affinity and enmity animating them.

\section{Extraction offsets, fossil fuels and climate concerns}

The extraction-conservation nexus is largely animated by a common politics of affinity and enmity; one that reinforces neo-liberal forms of territorialization that materialize valuations of 'nature' as 'extractable' resources or 'substitutable' biodiversity, rather than as embodied socio-natures with unique histories, cultures, practices and aspirations. In this regard, policies of 'ecological compensation' are on the rise as they gain support among some conservationists and become mobilized by corporations (e.g. Anglo American to try to break EU Natura protections) in order to open mines in ecologically sensitive areas through the promise conservation biodiversity 'equivalents' in areas elsewhere. ${ }^{9}$ These politics can be harmful for local communities through regimes of 'double exception' imposing restriction on their settlements, livelihoods, and socioenvironmental relations. Whereas the socioenvironmental outcomes of these extraction offsets and natural climate solutions may not always be negative for communities, they reflect uneven power relations that often result in limited forms of prior consultation, selective forms of compensation and exploitative forms of inclusion, as well as outright forms of oppression. The two cases selected here seek to illustrate some of these dimensions. I do not claim that they are representative of more general trends, but I seek to show how the extraction-conservation nexus can involve a politics of enmity and processes of double exception that harm some local communities. The first case study, in South Africa, highlights the ways in which biodiversity offsets can pave the way to the opening up of new spaces of coal extraction. The second briefly exposes the context through which supposedly well-intentioned 'biodiversity offsets' compensating for the devastation of agroindustrial projects can turn into a process of further dispossession and repression of historically marginalized Indigenous and Afro-Brazilian communities.

\section{Coal mining offsets in South Africa}

Coal is a key target of climate change mitigation efforts to curtail fossil fuel production (Gaulin and Le Billon 2019). Yet, despite more than a decade of staunch local and international opposition to an open-pit coal mine in the buffer area of the Mapungubwe National Park and UNESCO World Heritage Site, the South African government issued a license to the Vele Colliery, using the condition of a 'biodiversity offset' to legitimate its much-decried decision. Signed in 2014 - four years after the mining company was allowed to start operations ${ }^{10}$ - the offset agreement unlocking 720 million tons of coking coal gave way to selfcongratulatory statements by high ranking South African officials. For the Acting Director General of Environmental Affairs, the agreement marked:

\footnotetext{
${ }^{9}$ I thank a reviewer. See also Lassila (2020).

10 Jenner and Balmforth (2015: 20) note in this regard that such retrospective offsets "have the potential to disproportionately influence perceptions of transparency and accountability within the system."
} 
...a momentous stage in our country's development, where sectors originally perceived to have competing mandates, have realised the common vision of growth and prosperity for our country, and are beginning to walk this path towards sustainability together. (GoRSA 2014)

For the Chairman of the board for South African national parks (SANParks), this politics of affinity between government-led conservation and extractive corporations was seen not as something new, but rather as the logical outcome of a long-held policy of supposedly establishing parks for (rural) development, arguing that:

There are those who have insisted on seeing conservation as being opposed to development and job creation, but this is certainly not the case. SANParks has long held the view that our national parks should serve as catalysts for local economic development, particularly in some of the more isolated rural areas where opportunities are limited. (ibid)

Posing as a 'win-win' solution for conservation and extraction under the banner of sustainable growth and prosperity, the first statement sounded more hollow when considering that the mine's reserves would not only affect the local environment but also potentially unlock the equivalent of 2 billion tons of $\mathrm{CO}^{2}$, about five times the annual fossil emissions of South Africa. The second statement was also objectionable when considering the racist history of dispossession by conservation areas in the region and the broad coalition of local communities and land owners that had vocally opposed the mine out of concerns for its impacts on their livelihoods (see Leonard and Lebogang 2018; Sinthumule et al. 2020).

Beyond the discursive imaginaries of this offset, assessments of its material impacts were all the more difficult as only the legal framework of the agreement was (at least initially) publicly released, but not the key annexures detailing the agreed-upon activities (SMC 2014). Furthermore, the offset did not actually consist of a physical offset - in the sense of an additional area set aside for conservation purposes - but rather in payments to SANParks supposed to be made by installments over the estimated 38 years of mining operations. While such an absence of spatial offset may reduce its impacts on local populations by avoiding further dispossession, previous experiences of offsets made by budget support have tended to see local populations experience more forceful forms of conservation enforcement, as noted above. Following suit on the offset-based government approval process for the Vele Colliery, as well as De Beers's success in getting UNESCO to exclude its Venetia diamond mine from the Mapungubwe buffer area, more companies pushed for mining projects in the area. By early 2020, at least 23 mining prospecting licences had been granted in close proximity or even within the Mapungubwe National Park (Groenewald 2020). This suggests that offset schemes can not only or actively promote extractive schemes with major socio-environmental and climate impacts, ${ }^{11}$ but also reinforce systems of value production, deepening logics of extraction and increasing greenhouse gas emissions. As suggested below, the contradiction of instrumenting biodiversity conservation for the purpose of fossil fuel extraction should push COs to ban such partnerships. In contrast to claims of 'win-win' sustainable development bringing about 'green extraction' in support of 'crisis conservation', the extraction-conservation nexus entrenches the deadly logics of extractivism and colonial forms of environmentalism.

\section{Agro-extraction offsets in the Brazilian Cerrado}

Large-scale industrial farming is a key threat to biodiversity, carbon sinks, and traditional agrarian communities (Marques et al. 2019). The agro-industrial extraction of land and water for the purpose of extensive cash crop plantations has drastically affected ecosystems and traditional livelihoods in the Cerrado, a high savannah area mostly consisting of extensive plateaus cut by valleys. The second largest biome in Brazil after Amazonia, the Cerrado is a remote and biodiversity rich area (Klink and Machado 2005), traditionally inhabited by Indigenous people, Afro-Brazilians (quilombolas), and white settlers (geraizeros). The traditional populations, dwelling in valleys zones, mostly relied on hunting, fishing, free-range cattle raising and some agriculture. Land conflicts increased from the 1970s onwards, notably as a result of large-scale agri-businesses

\footnotetext{
${ }^{11}$ For climate change impacts on Mapungubwe, see for example Taylor and Bertrams (2020).
} 
and ranching, some of which tied in with irrigation projects and eucalyptus plantations (Shankland et al. 2016). By the mid-1990s, soja (Glycine max), sold mainly as an agro-industrial feedstock, saw growing international demand and production boomed, enabled by 'green revolution' technologies that extensively transformed landscapes, ecosystems and the social worlds of a region extending from the southern fringes of the Amazon to the Argentinian Chaco (Oliveira and Hecht 2016).

Initially focused on the rainfed plateau that provided hunting and grazing grounds for traditional peoples, agri-businesses have increased their pressure on local communities as they further extended the cropped area, polluted the watershed through pesticides, and restricted freedom of movement across vast areas. The agro-industrial lobby pushed for Forest Code reform on environmental restrictions to grant amnesties and legitimate illegal clearings. Among seemingly environmental progressive reforms, the Forest Code required agri-businesses to set aside an area representing $20 \%$ of their cultivated areas for conservation purposes, within the same biome category and hydrographic basin (Alves et al. 2018). While some agri-businesses did limit land clearing for cultivation within their existing concessions, others have taken advantage of this policy to further assert dubious land titles or acquire areas over traditional community lands. Conservation thus enabled the further extension of cultivation on the flat areas of the plateau, while further constraining or even displacing traditional communities in the valleys. Communities and social movements have denounced this conservationdriven process as 'green grabbing', "nothing more than a way to regularize, by means of the new environmental legislation, land grabbing" (Alves 2018: 564).

In the municipality of Formosa do Rio Preto, Bahia, an agro-industrial group operating a 305,000 ha estate has come under heavy criticism for land grabbing and the persecution of local traditional communities (Jordan 2019). Dubbed as a form of 'agro-terrorism', the pressures put on traditional communities have included travel restrictions, abduction and harming of cattle, illegal detentions, and brutalities towards community members. In January 2019, a community member was shot and injured by the estate's security company as he attempted to get his cattle back (Milhorance 2019). Local police have generally sided with the estate, arresting and bullying community members expressing their grievances. While the agro-industrial group mostly grows soja and cotton on the plateau, it is also seeking to control the valleys to satisfy conservation requirements without reducing more economically productive areas of the farmed plateau. The conservation rules associated with these biodiversity offsets also offer the agro-industrial group opportunities to further coerce local communities into limiting their traditional livelihood activities and possibly evict them from their ancestral territories (on the broader situation in Brazil under Bolsonaro, see Deutsch 2021).

\section{Conclusion}

Crisis conservation and green extraction have produced seemingly odd partners. Conservation is supposed to fend off extraction, but neoliberal logics have led many conservation organizations to hypocritically embrace extractive corporations eager to revamp their image as defenders of the environment. Beyond opportunistic funding and green-washing, affinities between conservation and extraction also rest on a readiness to dispossess in the name of a 'greater cause', whether through de-humanized understandings of biodiversity or false promises of economic development. While potentially progressive, the agenda pursued by the conservation-extraction nexus is at risk of facilitating the opening up of lands to large-scale extraction, while closing others to traditional livelihoods and communities. In this respect, I have attempted to make several contributions.

The first one is to help explain the paradoxical yet increasing convergence of extraction and conservation and their growing mutual dependence. The neoliberalization and growth of extractive and conservation activities mean that extraction increasingly needs to partner with conservation to access land and show environmental credentials. In turn, conservation projects benefit from extractive industry funding, its land-base, and its support by the ruling elite. These relations are not only pragmatic, but also reflect shared discursive imaginaries and material practices regarding (future) valuations of nature. As such the extractionconservation nexus is not only a marriage of convenience, but also a mutually reinforcing system of value production (and destruction). The closer the ties, the more likely it is that this system can overrule existing alternatives - such as independent conservation organizations openly criticizing and opposing extractive 
corporations, or local communities able to resist rather than being disposessed and selectively integrated through extraction/conservation social responsibility programs.

The second contribution is to clarify a typology of spaces of 'double exception' in relation to extraction and conservation. As suggested here, extraction-conservation partnerships notably take shape through extractive areas within protected areas ('degazetted PAs'); protected areas within or around extractive areas to legitimize and/or secure extractive activities ('integrated or adjoining PAs'); conservation areas overlaid on (former) extractive areas ('reclaimed or cover-up PAs') and zones of extraction being offsetted through protected areas ('biodiversity offsetting PAs'). Empirically, I briefly illustrated some of the spaces, including biodiversity offsets for agro-industrial projects and fossil fuel companies.

The third is to contrast the politics of affinities and enmities between conservation and extraction, with a focus on their shared enmity against local populations constituting a threat to their valuation of 'nature', their model of 'sustainable development', and their reproductive interests. Whereas the extinction crisis in part results from unfettered capitalism, runaway resource extraction, and environmentally devastating forms of consumerism, the common politics of enmity between extraction and conservation is creating new forms of value from nature. These include conservation opening up of new lands and providing legitimation narratives for extraction. Many local communities, from this perspective, pose a threat to both conservation and extraction through their land rights, traditional livelihoods, and defense of agrarian cultures and landscapes. As conservation and extraction partnerships seek to 'harness nature' through spaces of double exception, a common politics of enminity directed at local communities yet again legitimizes exclusionary practices rather than solving capitalism's contradictions.

Beyond these contributions, there are several broad implications that deserve attention, including (i) conservation movement strategies: what strategies (and tactics) should conservation movements adopt in order to reduce the undue influence of extractive interests on their funding and programming? Strategies could include a common set of principles and guidelines for COs vis à vis extractive companies and projects (e.g. reiterating the basic notion of conservation in relation to extraction; excluding certain extractive sectors, such as fossil fuels given the climate crisis, and projects, such as those involving open pit mining, tailing dams, or heavy metals effluent given their broad and long-lasting environmental impacts, or those displacing traditional communities). They could also operate due dilenge on the social, environmental and economic track record of the extractive corporations they are dealing with and offer full disclosure of any agreements and financial relations between COs and extractive companies. Secondly (ii), relationships between conservation, extraction and communities, especially with regard to prior consultation and consent processes. How to avoid the instrumentalization of conservation schemes to advance extractive projects at the expense of local communities, or vice-versa? FPIC principles should be applied to both extraction and conservation projects, with clear and accessible information and consultation on the likely outcomes of their relationships. (iii) Epistemologies of the corporate form: how can COs prevent their further corporatization? Reducing the influence of extractive corporations and extractivist logics, including with regard to board membership, finances, 'business models' and programmes. At the same time, COs can increase their assistance to (potentially) affected communities. This is key to advancing or maintaining convivial conservation that is both people and biodiversity focused (Büscher and Fletcher 2020). Lastly, state-society-business relationships. How can COs use their capacity to redress some of the deep inequalities that enable extractive activities to take place? Solidarity with marginalized populations can involve informing state authorities and the general public of the consequences of extraction, as well as holding extractive companies and authorities to account in terms of promises made or abuses committed.

Further research and policy consideration could help better understand some of these implications. This includes systematic comparative research on the types of relationships between extractive and conservation projects to help identify the potential determinants of partnerships, including the characteristics of firms and conservation organizations. Also, to investigate the (perceived) impact of their operations among local communities, national and international environmental groups, consumers, and investors. The responsiveness of national authorities to conservation agendas needs investigation, including whether companies need to 'take charge' or can argue that the government is sufficiently well-funded and capable of running its own 
conservation. Lastly, there is leverage among the demands of communities, including those that do not want conservation. In terms of policy, community-focused conservation could inform principles and practices of (dis)engagement from extraction.

\section{Bibliography}

Acosta, A. 2013. Extractivism and neoextractivism: two sides of the same curse. In Lang, M., L. Fernando and N. Buxton (eds). Beyond development: alternative visions from Latin America, (pp. 61-86). Amsterdam: Transnational Institute.

Adams, W.M. 2017. Sleeping with the enemy? Biodiversity conservation, corporations and the green economy. Journal of Political Ecology 24: 243-257. https://doi.org/10.2458/v24i1.20804

Ali, S.H., K. Sturman, and N. Collins (eds). 2018. Africa's mineral fortune: the science and politics of mining and sustainable development. Routledge.

Alves, V.E.L., M.L.C. Nóbrega, and E.G.J. Kluck. 2018. O avanço da violencia contra as communidaded agroextrativistas camponesas no espaço regional do Matopiba e pré-Amazonia. Revista OKARA: Geografia em debate 12(2): 549-576.

Andrews, T., Elizalde, B., Le Billon, P., Oh, C. H., Reyes, D., \& Thomson, I. 2017. The rise in conflict associated with mining operations: what lies beneath. Canadian International Resources and Development Institute.

Apostolopoulou, E., \& Adams, W.M. 2017. Biodiversity offsetting and conservation: reframing nature to save it. Oryx 51(1): 23-31. https://doi.org/10.1017/S0030605315000782

Bebbington, A.J., L. Hinojosa, D.H. Bebbington, M.L. Burneo, and X. Warnaars. 2008. Contention and ambiguity: Mining and the possibilities of development. Development and Change 39(6): 887-914.

Bebbington, A. J., D.H. Bebbington, L.A. Sauls, J. Rogan, S.Agrawal, C. Gamboa, ... \& T. Toumbourou. 2018. Resource extraction and infrastructure threaten forest cover and community rights. Proceedings of the National Academy of Sciences 115(52): 13164-13173. https://doi.org/10.1073/pnas.1812505115

Bennett, N. J., A.M. Cisneros-Montemayor, J. Blythe, J.J Silver, G. Singh, N. Andrews, ... \& S. Gelcich. 2019. Towards a sustainable and equitable blue economy. Nature Sustainability 2(11): 991-993.

Bidaud, C., K. Schreckenberg, M. Rabeharison, P. Ranjatson, J. Gibbons, and J.P. Jones. 2017. The sweet and bitter: Intertwined positive and negative social impacts of a biodiversity offset. Conservation and Society 15(1): 1-13. Http://doi.org/10.4103/0972-4923.196315

Boon, M. 2019. A climate of change? The oil industry and decarbonization in historical perspective. Business History Review 93(1): 101-125. http://doi.org/10.1017/S0007680519000321

Boonzaier, E. 2011. An 'historic victory 'for the Basarwa in Botswana? Reading the evidence. Anthropology Southern Africa 34(3-4): 96-103.

Bowles, I. A., and G.T. Prickett (eds.). 2001. Footprints in the jungle: natural resource industries, infrastructure, and biodiversity conservation. Oxford University Press.

Bridge, G. 2001. Resource triumphalism: postindustrial narratives of primary commodity production. Environment and Planning A 33(12): 2149-2173.

Bridge, G. 2004. Mapping the bonanza: geographies of mining investment in an era of neoliberal reform. The Professional Geographer 56(3): 406-421.

Bridge, G. 2008. Global production networks and the extractive sector: Governing resource-based development. Journal of Economic Geography 8(3): 389-419.

Bridge, G., \& P. Le Billon. 2017. Oil. Wiley.

Brock, A. 2020. Securing accumulation by restoration-Exploring spectacular corporate conservation, coal mining and biodiversity compensation in the German Rhineland. Environment and Planning E: Nature and Space https://doi.org/10.1177/2514848620924597

Bull, J. W., and N. Strange. 2018. The global extent of biodiversity offset implementation under no net loss policies. Nature Sustainability 1(12): 790-798. 
Büscher, B. 2021. Between overstocking and extinction: conservation and the intensification of uneven wildlife geographies in Africa. Journal of Political Ecology 28(1): 760-781. https://doi.org/10.2458/jpe.2956

Büscher, B., and V. Davidov. 2016. Environmentally induced displacements in the ecotourism-extraction nexus. Area 48(2): 161-167.

Büscher, B., \& Fletcher, R. 2015. Accumulation by conservation. New Political Economy 20(2): 273-298.

Büscher, B., \& Fletcher, R. 2020. The conservation revolution: radical ideas for saving nature beyond the Anthropocene. Verso.

Büscher, B., R. Fletcher, D. Brockington, C. Sandbrook, W.M. Adams, L. Campbell, ... \& G. Holmes. 2017. Half-Earth or Whole Earth? Radical ideas for conservation, and their implications. Oryx 51(3): 407410.

Büscher, B., S. Sullivan, K. Neves, J. Igoe and D. Brockington. 2012. Towards a synthesized critique of neoliberal biodiversity conservation. Capitalism, Nature, Socialism 23: 4-30.

Butt, N., H. L. Beyer, J. R. Bennett, D. Biggs, R. Maggini, M. Mills, A. R. Renwick, L. M. Seabrook, and H. P. Possingham. 2013. Biodiversity risks from fossil fuel extraction. Science 342(6157): 425-426.

Chaney, R. 2011. British Columbia OKs law protecting Flathead Basin. The Missoulian, 16 November. [accessed October 16 2020]. https://missoulian.com/news/local/british-columbia-oks-law-protectingflathead-basin/article_9849453e-1098-11e1-8a04-001cc4c03286.html

Chapin, M. 2004. A challenge to conservationists. World Watch (November/December): 17-31.

CI. 2014. Conservation International Foundation and Affiliates. Consolidated Financial Report June $30,2014$. https://www.conservation.org/docs/default-source/publicationpdfs/ci_2014_financials.pdf?sfvrsn=734f04a8_3

CI. 2019. What If.... CI Annual Report 2018. Conservation International [accessed October 162020 ]. https://www.conservation.org/docs/default-source/do-notcrawl/fy18_annual_report_donors.pdf?sfvrsn=44e0ad8b_4

Colchester, M. 2004. Conservation policy and indigenous peoples. Environmental Science \& Policy 7(3): 145153.

Condé, M., and P. Le Billon. 2017. Why do some communities resist mining projects while others do not? The Extractive Industries and Society 4(3): 681-697.

Dahl, T., and Fløttum, K. 2019. Climate change as a corporate strategy issue. Corporate Communications: an International Journal 24(3): 499-514.

Dahlgren, K. 2019. Blaming in the boom and bust: greed accusations in an Australian coal mining town. The Cambridge Journal of Anthropology 37(2): 90-109.

Davidov, V., and Büscher, B. 2013. Introduction: the ecotourism-extraction nexus. In Büscher, B. and V. Davidov (eds). The ecotourism-extraction nexus. (pp. 21-36). Routledge.

De Beers. 2018. Biodiversity and conservation. [accessed October $16 \quad 2020$ ]. https://www.debeersgroup.com/building-forever/reporting/environment/biodiversity-and-conservation

Dempsey, J. and R.C. Collard. 2017. If biodiversity offsets are a dead end for conservation, what is the live wire? A response to Apostolopoulou \& Adams. Oryx 51(1): 35-39. http://doi.org/10.1017/S0030605316000752

Dempsey, J., and D.C. Suarez. 2016. Arrested development? The promises and paradoxes of 'selling nature to save it.' Nature and Society 106(3): 653-671.

Deutsch, S., 2021. Populist authoritarian neoliberalism in Brazil: making sense of Bolsonaro's antienvironment agenda. Journal of Political Ecology 28(1): 823-844. https://doi.org/10.2458/jpe.2994

Díaz, S., J. Settele, E.S. Brondízio, H.T. Ngo, J. Agard, A. Arneth, ... \& L.A. Garibaldi. 2019. Pervasive human-driven decline of life on Earth points to the need for transformative change. Science 366(6471). http://doi.org/10.1126/science.aax3100

Douglas, L. R., and K. Alie. 2014. High-value natural resources: Linking wildlife conservation to international conflict, insecurity, and development concerns. Biological Conservation 171: 270-277. 
DPL. 2012. Conservation International Greenwash. 2 March. Don't Panic London [accessed October 16 2020]. https://www.youtube.com/watch?v=QsRGXsEGG8Q

Duffy, R. 2006. The politics of ecotourism and the developing world. Journal of Ecotourism 5(1-2): 1-6.

Duffy, R. 2014. Waging a war to save biodiversity: the rise of militarized conservation. International Affairs 90(4): 819-834.

Dunlap, A., and J. Jakobsen. 2020. The violent technologies of extraction. Palgrave Pivot.

Durán, A. P., J. Rauch, and K.J. Gaston. 2013. Global spatial coincidence between protected areas and metal mining activities. Biological Conservation 160: 272-278.

Enns, C., B. Bersaglio, and A. Sneyd. 2019. Fixing extraction through conservation: on crises, fixes and the production of shared value and threat. Environment and Planning E: Nature and Space 2(4): 967-988.

Evans, S. 2019. Q\&A: the inside track on BHP \& Conservation International's unlikely partnership. 4 December. [accessed October 16 2020]. https://www.mining-technology.com/features/the-inside-trackon-bhp-conservation-internationals-unlikely-partnership/

Finer, M., C.N. Jenkins, S.L. Pimm, B. Keane, and C. Ross. 2008. Oil and gas projects in the western Amazon: threats to wilderness, biodiversity, and indigenous peoples. PloS One 3(8): e2932. https://doi.org/10.1371/journal.pone.0002932

Fisher, J.T., and A.C. Burton. 2018. Wildlife winners and losers in an oil sands landscape. Frontiers in Ecology and the Environment 16(6): 323-328.

Gaulin, N., and P. Le Billon. 2020. Climate change and fossil fuel production cuts: Assessing global supplyside constraints and policy implications. Climate Policy 20(8): 888-901.

GoRSA. 2014. Historic biodiversity offset agreement signed by the Department of Environmental Affairs, SANPARKS and Coal of Africa for Vele Colliery. [accessed October 16 2020]. https://www.environment.gov.za/historic_biodiversity_offset_agreement_signed_department_environ mental_affairs_sanparks_and_coal_afr

Kay, K. and M. Keney-Lazar. 2017. Valuing in capitalist natures: an emerging framework. Dialogues in Human Geography 7(3): 295-309.

Kelly, A.B. 2011. Conservation practice as primitive accumulation. Journal of Peasant Studies 38(4): 683-701.

Kröger, M. 2018. The new 'sustainable communitarian' logging schemes and their critique inside multiple-use conservation areas in the Brazilian Amazon: preliminary notes. Globalizations 15(5): 581-592.

Kröger, M. 2020. Deforestation, cattle capitalism and neodevelopmentalism in the Chico Mendes Extractive Reserve, Brazil. Journal of Peasant Studies 47(3): 464-482.

Kroner, R.E.G., S. Qin, C.N. Cook, R. Krithivasan, S.M. Pack, O.D. Bonilla, ... \& Y. He. 2019. The uncertain future of protected lands and waters. Science 364(6443): 881-886. http://doi.org/10.1126/science.aau5525

Hackett, R. 2015. Offsetting dispossession? Terrestrial conservation offsets and First Nation treaty rights in Alberta, Canada. Geoforum 60: 62-71.

Hackett, R. 2016. 'Shell games', displacement and the reordering of boreal landscapes in Alberta, Canada. Area 48:153-160.

Hamann, R. and P. Kapelus. 2004. Corporate social responsibility in mining in Southern Africa: Fair accountability or just greenwash? Development 47(3): 85-92.

Hance, J. 2016. How big donors and corporations shape conservation goals. Mongabay, 3 May. [accessed 28 Aug 2021] https://news.mongabay.com/2016/05/big-donors-corporations-shape-conservation-goals/

Hill, W., J. Byrne, and F. de Vasconcellos Pegas. 2016. The ecotourism-extraction nexus and its implications for the long-term sustainability of protected areas: what is being sustained and who decides? Journal of Political Ecology 23(1): 308-327. https://doi.org/10.2458/v23i1.20219

Hoffman, A.J. 2009. Shades of green. Stanford Social Innovation Review. Spring: 40-49.

Holmes, G. 2012. Biodiversity for billionaires: capitalism, conservation and the role of philanthropy in saving/selling nature. Development and Change 43(1): 185-203. 
Huff, A., and Y. Orengo. 2020. Resource warfare, pacification and the spectacle of 'green'development: Logics of violence in engineering extraction in southern Madagascar. Political Geography 81: 102195.

ICMM. 2006. Good practice guidance for mining and biodiversity. International Council on Mining and Metals. [accessed 27 Aug 2021] http://www.icmm.com/en-gb/guidance/environmentalstewardship/good-practice-mining-biodiversity

Igoe, J., K. Neves, and D. Brockington. 2010. A spectacular eco-tour around the historic bloc: theorising the convergence of biodiversity conservation and capitalist expansion. Antipode 42(3): 486-512.

IMDC. 2014. Mining and agriculture. International Mining for Development Centre.

Jenner, N., and Z. Balmforth. 2015. Biodiversity offsets: lessons learnt from policy and practice. Fauna and Flora International, Cambridge, UK. [accessed Aug 27 2021] https://cms.fauna-flora.org/wpcontent/uploads/2017/12/FFI_2015_Biodiversity-Offsets-Synthesis-Report.pdf

Jonas, H. D., Lee, E., Jonas, H. C., Matallana-Tobon, C., Wright, K. S., Nelson, F., \& Enns, E. 2017. Will 'other effective area-based conservation measures' increase recognition and support for ICCAs? Parks 23(2): 63-78. https://doi.org/10.2305/IUCN.CH.2017.PARKS-23-2HDJ.en

Jordan, L. 2019. Soy traders going 'deforestation-free' still fuelling destruction of Brazil's Cerrado. Unearthed. Greenpeace. https://unearthed.greenpeace.org/2019/12/04/brazil-cerrado-soy-bunge-cargill [accessed October 16 2020].

Junka-Aikio, L. and C. Cortes-Severino. 2017. Cultural studies of extraction. Cultural Studies 3(2-3): 175-184.

Klink, C.A., and R.B. Machado. 2005. Conservation of the Brazilian cerrado. Conservation Biology 19(3): 707-713.

Kroner, R.E.G., S. Qin, C.N. Cook, R. Krithivasan, S.M. Pack, O.D. Bonilla, ... and Y. He. 2019. The uncertain future of protected lands and waters. Science 364(6443): 881-886. http://doi.org/10.1126/science.aau5525

Lassila, M. 2020. The Arctic mineral resource rush and the ontological struggle for the Viiankiaapa peatland in Sodankylä, Finland. Globalizations 18(4): 635-649.

Le Billon, P. 2012. Wars of plunder: conflicts, profits and the politics of resources. Columbia University Press.

Le Billon, P., and Kristoffersen, B. 2020. Just cuts for fossil fuels? Supply-side carbon constraints and energy transition. Environment and Planning A: Economy and Space 52(6): 1072-1092.

Le Billon, P., and P. Lujala. 2020. Environmental and land defenders: Global patterns and determinants of repression. Global Environmental Change 65: 102163.

Le Billon, P., and M. Sommerville. 2017. Landing capital and assembling 'investable land' in the extractive and agricultural sectors. Geoforum 82: 212-224.

Le Meur, P. Y., Levacher, C., Bouard, S., Herrenschmidt, J. B., \& Sabinot, C. 2020. Mining and the value of place in New Caledonia: negotiation, evaluation, recognition. The Extractive Industries and Society 8(1): 44-54.

Leonard, L., and T. Lebogang. 2018. Exploring the impacts of mining on tourism growth and local sustainability: The case of Mapungubwe Heritage Site, Limpopo, South Africa. Sustainable Development 26(3): 206-216.

Levitt, T. 2011. Conservation International 'agreed to greenwash arms company.' The Ecologist. 11 May. [accessed October 16 2020]. https://theecologist.org/2011/may/11/conservation-international-agreedgreenwash-arms-company

Li, F. 2015. Unearthing conflict: corporate mining, activism, and expertise in Peru. Duke University Press.

MAC. 2017. Towards sustainable mining: biodiversity conservation management protocol. Mining Association of Canada.

MacDonald, C. 2008. Green, Inc: an environmental insider reveals how a good cause has gone bad. Rowman \& Littlefield.

Maron, M., A. Gordon, B.G. Mackey, H.P. Possingham, and J.E. Watson. 2015. Conservation: stop misuse of biodiversity offsets. Nature 523(7561): 401-403. https://doi.org/10.1038/523401a 
Marques, A., Martins, I. S., Kastner, T., Plutzar, C., Theurl, M. C., Eisenmenger, N., ... \& Pereira, H. M. 2019. Increasing impacts of land use on biodiversity and carbon sequestration driven by population and economic growth. Nature Ecology \& Evolution 3(4): 628-637.

Mascia, M. B., and S. Pailler. 2011. Protected area downgrading, downsizing, and degazettement (PADDD) and its conservation implications. Conservation Letters 4(1): 9-20. https://doi.org/10.1111/j.1755263X.2010.00147.x

Mbembe, A. 2001. On the postcolony. University of California Press.

Mbembe, A. 2019. Necropolitics. Duke University Press.

Meijaard, E., D. Sheil, R. Nasi, D. Augeri, B. Rosenbaum, D. Iskandar, ... and T. O'Brien. 2005. Life after logging: reconciling wildlife conservation and production forestry in Indonesian Borneo. CIFOR. https://doi.org/10.17528/cifor/001663

Menton, M., and P. Le Billon. 2021. Environmental defenders: Deadly struggles for life and territory. Routledge.

Middeldorp, N., and P. Le Billon. 2019. Deadly environmental governance: authoritarianism, eco-populism, and the repression of environmental and land defenders. Annals of the American Association of Geographers 109(2): 324-337.

Middeldorp, N., and P. Le Billon. 2021. Empowerment or imposition? Extractive violence, Indigenous peoples and the paradox of prior consultation. In, Shapiro, J. and McNeish, J-A. (eds.). Our hyper-extractive age: expressions of violence and resistance. Routledge. https://doi.org/10.4324/9781003127611

Milhorance, F. 2019. Cerrado farmer shot amid escalating conflict with agribusiness. Mongabay, 21 February. [accessed 27 Aug 2021] https://news.mongabay.com/2019/02/video-cerrado-farmer-shot-amidescalating-conflict-with-agribusiness/

Moss, J. 2019. Australia's Carbon Majors Report 2019. Practical Justice Initiative. UNSW.

Mosweunyane, D. 2017. Brutal development agenda by political panjandrums in Botswana: how CKGR evictions massacred the native citizens (Basarwa) through HIV/AIDS. African Educational Research Journal 5(1): 75-90.

Mudroch, A., U. Stottmeister, C. Kennedy, and H. Klapper (eds.). 2002. Remediation of abandoned surface coal mining sites: a NATO-Project. Springer.

Murguía, D. I., S. Bringezu, and R. Schaldach. 2016. Global direct pressures on biodiversity by large-scale metal mining: spatial distribution and implications for conservation. Journal of Environmental Management 180: 409-420.

Naughton-Treves, L., and M.B. Holland. 2019. Losing ground in protected areas? Science 364(6443): 832833.

Navas, G., S. Mingorria, and B. Aguilar-González. 2018. Violence in environmental conflicts: the need for a multidimensional approach. Sustainability Science 13(3): 649-660. https://doi.org/10.1007/s11625$\underline{018-0551-8}$

Nazari, M., and D. Proebstel. 2008. Biodiversity offsets in mining. Canadian Mining Journal, 21 September. http://www.canadianminingjournal.com/news/canadian-mining-perspectives-biodiversity-offsets-inmining

Neimark, B., and B. Wilson. 2015. Re-mining the collections: from bioprospecting to biodiversity offsetting in Madagascar. Geoforum 66: 1-10.

Neumann, R.P. 2004. Moral and discursive geographies in the war for biodiversity in Africa. Political Geography 23(7): 813-837.

Newing, H., and A. Perram. 2019. What do you know about conservation and human rights? Oryx 53(4): 595596. https://doi.org/10.1017/S0030605319000917

Norris, T. B. 2017. Shared Social License: mining and conservation in the Peruvian Andes. Antipode 49(3): 721-741. 
O'Connor, J. 1988. Capitalism, nature, socialism: a theoretical introduction. Capitalism, Nature, Socialism 1(1): 11-38.

Oliveira, G., and S. Hecht. 2016. Sacred groves, sacrifice zones and soy production: globalization, intensification and neo-nature in South America. Journal of Peasant Studies 43(2): 251-285. https://doi.org/10.1080/03066150.2016.1146705

Palmer, N. J., and N. Chuamuangphan. 2018. Governance and local participation in ecotourism: communitylevel ecotourism stakeholders in Chiang Rai province, Thailand. Journal of Ecotourism 17(3): 320-337.

Peluso, N.L. 1992. Rich forests, poor people: Resource control and resistance in Java. University of California Press.

Peluso, N.L. 1993. Coercing conservation? The politics of state resource control. Global Environmental Change 3(2): 199-217.

PPLR. 2020. Protected Planet live report. [accessed October 16 2020]. https://livereport.protectedplanet.net/

Prause, L., and P. Le Billon. 2021. Struggles for land: comparing resistance movements against agro-industrial and mining investment projects. The Journal of Peasant Studies 48(5): 1100-1123.

Purwins, S. 2020. Bauxite mining at Atewa Forest Reserve, Ghana: a political ecology of a conservationexploitation conflict. GeoJournal. https://doi.org/10.1007/s10708-020-10303-3

Radford, P. 2012. The extraction industry must end. Greenpeace. 25 March. https://www.greenpeace.org/usa/the-extraction-industry-must-end

Read, K., and C. Diehl. 2018. The emergence and growth of strategic partnerships between NGOs and corporates. In Garsten, N. and I. Bruce (eds). Communicating causes: strategic public relations for the non-profit sector. Routledge.

Schulz, K.A. 2017. Decolonizing political ecology: ontology, technology and 'critical' enchantment. Journal of Political Ecology 24(1): 125-143. https://doi.org/10.2458/v24i1.20789

Seagle, C. 2012. Inverting the impacts: Mining, conservation and sustainability claims near the Rio Tinto/QMM ilmenite mine in Southeast Madagascar. Journal of Peasant Studies 39(2): 447-477.

Shankland, A., Z. Sullivan, C.A. Dayrell, A.C. Alvarenga, and D.F. Batista Rocha. 2016. 'Traditional Peoples' and the struggle for inclusive land governance in Brazil. ODI. https://opendocs.ids.ac.uk/opendocs/handle/20.500.12413/12185

Shaw, C. 2021. Defending territories of life through Indigenous and Community Conserved Areas (ICCAs). In Menton, M. and P. Le Billon (eds). Environmental defenders: deadly struggles for life and territory. Routledge.

Shell Canada. 2019. Conservation. [accessed Aug 27, 2021 https://www.shell.ca/en_ca/sustainability/environment/land-conservation.html

Sinthumule, N. I., T. Ratshivhadelo, and T. Nelwamondo. 2020. Stakeholder perspectives on land-use conflicts in the South African section of the Greater Mapungubwe Transfrontier Conservation Area. Journal of Land Use Science 15(1): 11-24.

SMC. 2014. Save Mapungubwe Coalition calls the biodiversity offset agreement for Vele Colliery "vague, inadequate and unenforceable." 30 October. [accessed October 16 2020]. https://cer.org.za/news/mediarelease-save-mapungubwe-coalition-calls-the-biodiversity-offset-agreement-for-vele-colliery-vagueinadequate-and-unenforceable

Smith, T.J. 2013. Crude desires and 'Green'initiatives: Indigenous development and oil extraction in Amazonian Ecuador. In Büscher, B. and V. Davidov (eds). The ecotourism-extraction nexus. (pp. 169190). Routledge.

Song, X.P., M.C. Hansen, S.V. Stehman., P.V. Potapov, A. Tyukavina, E.F. Vermote, and J.R. Townshend. 2018. Global land change from 1982 to 2016. Nature 560(7720): 639.

Sonter, L.J., S.H. Ali, and J.E. Watson. 2018. Mining and biodiversity: key issues and research needs in conservation science. Proceedings of the Royal Society B 285(1892): 20181926. https://doi.org/10.1098/rspb.2018.1926 
Sonter, L.J., D. Herrera, D. J. Barrett, G.L. Galford, C.J. Moran, and B.S. Soares-Filho. 2017. Mining drives extensive deforestation in the Brazilian Amazon. Nature Communications 8(1): 1013.

Sovacool, B. K., S.H. Ali, M. Bazilian, B. Radley, B. Nemery, J. Okatz, and D. Mulvaney. 2020. Sustainable minerals and metals for a low-carbon future. Science 367(6473): 30-33.

Spence, M.D. 1999. Dispossessing the wilderness: Indian removal and the making of the national parks. Oxford University Press.

Steneck, R.S., and D. Pauly. 2019. Fishing through the Anthropocene. Current Biology 29(19): R987-R992.

Sweeney, O. 2016. Queensland-style land management proposed for NSW: the Biodiversity Conservation and Local Land Service Amendment Bills. Nature New South Wales 60(3): 11-13.

Symons, K. 2018. The tangled politics of conservation and resource extraction in Mozambique's green economy. Journal of Political Ecology 25(1): 488-507. https://doi.org/10.2458/v25i1.22762

Taylor, M., and J. Watts. 2019. Revealed: The 20 firms behind a third of all carbon emissions. The Guardian.

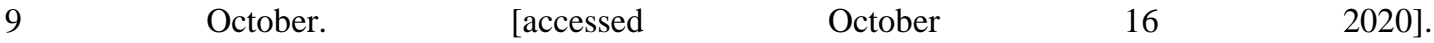
https://www.theguardian.com/environment/2019/oct/09/revealed-20-firms-third-carbon-emissions

Taylor, T., and N. Bertrams. 2020. They survived centuries of elephant onslaught. Now climate change is killing these iconic baobabs. Mongabay. 29 May. [accessed 28 Aug 2021] https://news.mongabay.com/2020/05/they-survived-centuries-of-elephant-onslaught-now-climatechange-is-killing-these-iconic-baobabs/

Temper, L., D. Del Bene, and J. Martinez-Alier. 2015. Mapping the frontiers and front lines of global environmental justice: the EJAtlas. Journal of Political Ecology 22(1): 255-278. https://doi.org/10.2458/v22i1.21108

Temper, L., Avila, S., Del Bene, D., Gobby, J., Kosoy, N.,... \& Walter, M. (2020). Movements shaping climate futures: A systematic mapping of protests against fossil fuel and low-carbon energy projects. Environmental Research Letters 15(12): 123004. https://doi.org/10.1088/1748-9326/abc197

Thakholi, L. (2021). The biopolitics of private conservation: jeopardizing labor and rhino to optimize capital? Journal of Political Ecology 28(1): 705-720. https://doi.org/10.2458/jpe.4764

TNCC. 2013. The Nature Conservancy of Canada applauds Teck Resources' commitment to land conservation. 18 October. The Nature Conservancy of Canada. [accessed October 16 2020]. https://www.newswire.ca/news-releases/the-nature-conservancy-of-canada-applauds-teck-resourcescommitment-to-land-conservation-513122081.html

Tsing, A.L. 2005. Friction: an ethnography of global connection. Princeton University Press.

UNEP-WCMC and IUCN. 2016. Protected Planet Report 2016. UNEP-WCMC and IUCN: Cambridge UK and Gland, Switzerland.

Van Vliet, N., D. Cornelis, H. Beck, P. Lindsey, R. Nasi, S. LeBel, ... \& F. Jori. 2016. Meat from the wild: extractive uses of wildlife and alternatives for sustainability. In Mateo, R., B. Arroya, and J.T. Garcia (eds.) Current trends in wildlife research. (pp. 225-265). Springer.

Vyawahare, M. 2020. Raze here, save there: Do biodiversity offsets work for people or ecosystems? Mongabay. 20 February. [accessed October 16 2020]. https://news.mongabay.com/2020/02/raze-here-save-theredo-biodiversity-offsets-work-for-people-or-ecosystems/

Veltmeyer, Henry. 2016. Extractive capital, the state and the resistance in Latin America. Sociology and Anthropology 4(8): 774-784.

Virah-Sawmy, M., J. Ebeling, and R. Taplin. 2014. Mining and biodiversity offsets: A transparent and sciencebased approach to measure 'no-net-loss.' Journal of Environmental Management 143: 61-70.

Walker, P. 1998. Politics of nature: an overview of political ecology. Capitalism Nature Socialism 9(1): 131144.

Watts M.J. 2000. Contested communities, malignant markets, and gilded governance: justice, resource extraction, and conservation in the Tropics. In Zerner, C. (ed.) Plants, people, and justice: The politics of nature conservation (pp 21-51). Columbia University Press. 
Watts, M.J. 2001. Petro-violence: Community, extraction, and political ecology of a mythic commodity. In Peluso, N. and Watts, M. (eds), Violent environments (pp 189-212). Cornell University Press.

Welker, M.A. 2009. 'Corporate security begins in the community': Mining, the corporate social responsibility industry, and environmental advocacy in Indonesia. Cultural Anthropology 24(1): 142-179.

World Bank. 2019. Forest-smart mining: Offset case studies. [accessed October 16 2020]. http://documents.worldbank.org/curated/en/775721560329518480/pdf/Forest-Smart-Mining-OffsetCase-Studies.pdf

World Mining Data. 2019. [accessed October 16 2020] https://www.world-miningdata.info/?World_Mining_Data__Data_Section

Wouters, J.J. 2020. Neoliberal capitalism and ethno-territoriality in Highland Northeast India: Resourceextraction, capitalist desires and ethnic closure. Geopolitics. 10.1080/14650045.2020.1812581

WRM. 2017. What goes behind the idea of biodiversity offsetting: the case of Nam Ngiep Dam in Lao PDR. Bulletin 232. [accessed October 16 2020]. https://wrm.org.uy/articles-from-the-wrmbulletin/section1/what-goes-behind-the-idea-of-biodiversity-offsetting-the-case-of-nam-ngiep-dam-inlao-pdr

WWF. 2019. Responsible oil, gas and mining. WWF-UK. [accessed October 16 2020]. https://www.wwf.org.uk/what-we-do/area-of-work/responsible-oil-gas-and-mining

Ye, J., van der Ploeg, J.D., Schneider, S. and Shanin, T., 2020. The incursions of extractivism: moving from dispersed places to global capitalism. The Journal of Peasant Studies 47(1): 155-183.

Zambia Eye. 2018. FQM Trident Foundation invests US\$2m in wildlife and conservation projects. 31 March. [accessed October 16 2020]. https://zambianeye.com/fqm-trident-foundation-invests-us2m-in-wildlifeand-conservation-projects 